\title{
Profile of Turbidity and Glucose Formation from Underutilised Wild, Edible Bean during In-Vitro Gastro Intestinal Digestion and Fermentation
}

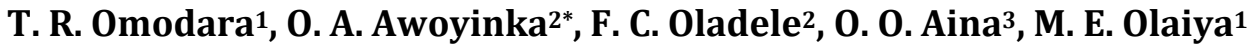 \\ ${ }^{1}$ Department of Microbiology, Faculty of Sciences, Ekiti State University, Ado Ekiti, Nigeria \\ ${ }^{2}$ Department of Medical Biochemistry, College of Medicine, Ekiti State University, Ado Ekiti, Nigeria \\ ${ }^{3}$ Department of Microbiology, Federal Teaching Hospital, Ido Ekiti, Nigeria \\ Email: *olayinka.awoyinka@eksu.edu.ng
}

How to cite this paper: Omodara, T.R., Awoyinka, O.A., Oladele, F.C., Aina, O.O. and Olaiya, M.E. (2018) Profile of Turbidity and Glucose Formation from Underutilised Wild, Edible Bean during In-Vitro Gastro Intestinal Digestion and Fermentation. Advances in Microbiology, 8, 994-1004. https://doi.org/10.4236/aim.2018.812067

Received: November 7, 2018

Accepted: December 24, 2018

Published: December 27, 2018

Copyright (c) 2018 by authors and Scientific Research Publishing Inc. This work is licensed under the Creative Commons Attribution International License (CC BY 4.0).

http://creativecommons.org/licenses/by/4.0/

c)

\begin{abstract}
Fermentation takes place throughout the gastrointestinal tract of all animals, but the intensity and products of fermentation depend on number and types microbes, which are generally highest in the large bowel. Large intestinal epithelial cells do not produce digestive enzymes, but contain huge numbers of bacteria which have the enzymes to digest and utilize many substrates. The seeds of beans (Otili, Feregede, Pakala and Oloyin) analyzed in this present study contain indigestible fraction called dietary fiber which helps to maintain functioning of the digestive system. Fermentation of indigestible fraction (IF) of these beans was mimicked through in-vitro method which leads to biochemical changes in the samples. During this experiment, increase in acidity and turbidity was observed. The glucose concentration decreases with some exceptions, such as Pakala fermented by Lactobacillus acidophilus which had the value of $6.260 \mathrm{mmol} / \mathrm{L}$ at $6 \mathrm{hr}$ and increased to $6.616 \mathrm{mmol} / \mathrm{L}$ after 18 hours fermentation, Otili fermented by various microorganisms which had its turbidity increased by $50 \%$. Lactobacillus acidophilus fermenting Pakala had the highest glucose concentration during the fermentation period. The increase in turbidity could be as a result of increase in microbial flora or production of metabolites, such as glucose. The approach followed here may be used as a predictive model to assess the metabolic implications of food substrates present in the traditional Nigerian orphan beans.
\end{abstract}

\section{Keywords}

Fermentation, Turbidity, Glucose, Indigestible-Fraction, Wild-Bean 


\section{Introduction}

Prebiotics are non-digestible but fermentable oligosaccharides that are specifically designed to change the composition and activity of the intestinal microbiota aimed at promoting the health of the host. Dietary fiber and non-digestible oligosaccharides are the main growth substrates of gut microorganisms. The bacterial population of the gut has been studied in diseases, such as colon cancer, inflammatory bowel diseases (IBD), hypercholesterolemia, non-alcoholic fatty liver disease (NAFLD) and others [1] [2].

Microbial metabolic end-products, which account for one third of the metabolites present in the human blood, play an important role in gut homeostasis and have an impact on host metabolism and health [3] [4] [5] [6] [7]. Non-digestible oligosaccharides are considered non-caloric agents because of their resistance to the hydrolytic action of digestive enzymes [8] [9]. Oligosaccharides are excellent prebiotics, because they act like growth factor to particular commensal bacteria, which inhibit the adherence and invasion of pathogens in the colonic epithelia by competing for the same glycoconjugates present on the surface of epithelial cells, altering the colonic $\mathrm{pH}$, favoring the barrier function, improving the mucus production, producing short-chain fatty acids and inducing cytokine production, promoting multiple benefits and better health [10] [11] [12]. These prebiotics effects can be evaluated on the basis of growth of bacteria, such as lactobacilli and bifidobacteria, the decrease of intestinal pathogens and the increase or decrease in production of health related bacterial metabolites [2] [13].

The ultimate aim of supplementation of the human diet with prebiotics is the beneficial management of the gut microbiota [5] [8]. Many non-digestible oligosaccharides beneficially affect the host by selectively stimulating the growth and/or activity of one or a limited number of beneficial bacteria in the colon, thereby improving host health [14] [15]. Also, it has been found out that changes in the microflora of gastro-intestine as a result of ingesting non-digestible oligosaccharides increase the protection of the human intestine by reducing the antagonist effects of pathogenic bacteria, thereby decreasing the intestinal infections, diarrhoea disease, stimulating the immune system and antigenotoxicity activities [16] [17] [18].

Interest in functional oligosaccharides is motivated by their diverse industrial applications in nutraceutical, pharmaceutical, prebiotics, cosmetics, animal feed and agriculture sector. The health benefits of functional oligosaccharides are well-known and far-reaching. Furthermore, oligosaccharides have been the subject of intensive and cutting-edge research during the last three decades in response to their ever-increasing demand [19] [20] [21] [22] [23]. To this end, several studies have focused their efforts on investigating the effect of some in the growth of intestinal microbiota [24] [25] [26]. Past and recent studies suggest that one can positively modify the contents of the gut microbiota by introducing prebiotics, probiotics, synbiotics and other therapeutics. Hence, this paper focuses on prebiotic tendency of under-utilized wild bean compared to a common edible bean and their possible inclusion of these wild underutilized to our diet. 


\section{Materials and Methods}

\subsection{Collection of Cultivar}

The legumes (beans) used in this work are of two types; Wild-type beans Sphenostyles stenocarp (Otili African yam bean), Cajanus cajan (Feregede Pigeon pea), Phaseolus lunatus (Pakala lima beans) and Edible bean Phaseolus vulgaris (Oloyin kidney bean). They are gotten from the farmers in Ado-Ekiti.

\subsection{Media}

Media used are; Nutrient agar, MRS agar, Peptone water. 15 grams of peptone powder was dissolved in $1000 \mathrm{ml}$ of distilled water to prepare peptone water. 5 grams of nutrient agar was dissolved in $178.6 \mathrm{ml}$ of distilled water. 5 grams of the MRS agar was dissolved in $75 \mathrm{ml}$ of distilled water to prepare MRS agar. The media are then sterilized in an autoclave at $121^{\circ} \mathrm{C}, 15$ Pascal for 15 minutes. Nutrient agar slants were also prepared to store used organisms.

\subsection{Extraction of Non Digestible Fraction}

The alkali-catalyzed hydrolysis method as described by Shimin et al., [27] was applied to extract the insoluble dietary fiber from the beans sample. The bean samples were prepared by pulverizing using blender. 20 grams of each sample was place in different beakers in quadruplicate followed by the addition of 25 milliliters of ethyl acetate to each sample. After 3 hours, the slurry was washed with water and dried with hot air at $55^{\circ} \mathrm{C}$ overnight. Sodium hydroxide was added at 20 times the volume of the slurry, and the mixture was then centrifuged at $4000 \mathrm{rpm}$ for $15 \mathrm{~min}$. The collected matter was then deposited and washed with water. The insoluble dietary fiber was recovered from the residue after the deposit was washed with $76 \%$ ethanol, $95 \%$ ethanol and acetone at 4 times the volume of the slurry and dried with hot air at $55^{\circ} \mathrm{C}$ overnight. The insoluble dietary fiber content in the final bean samples extract was approximately $40 \%$, while the other $60 \%$ of the extract was nitrogen free extract (NFE). The content of IDF was determined according to GB 5009.88-2014.

\subsection{Isolation of Organisms}

Lactobacillus acidophilus was isolated from milk gotten from Ayetoro Ekiti using the MRS agar. The other microorganisms (Enterococcus feacalis, Escherichia coli, Streptococcus pyogens, Staphylococcus aureus and Bacillus subtilis) used were obtained from the Microbiology Laboratory, Ekiti state University, Ado Ekiti. One loopful from the stocks was dispensed into $9 \mathrm{ml}$ of distilled water and serial diluted in dilution $10^{-1}$ to $10^{-7}$. A loopful was then inoculated into the MRS agar, nutrient agar and peptone water. From the pure culture a loopful were inoculated into the nutrient slant for preservation.

\subsection{In Vitro Gastrointestinal Fermentation}

In vitro colonic fermentation Total Indigestible Fraction isolated from the bean 
was fermented in disposable test tubes prepared with Peptone water under strict anaerobic conditions, at $37^{\circ} \mathrm{C}$ [28]. A 1:10 (w/v) dilution of selected gastrointestinal microbes (Escherichia coli, Bacillus subtilis, Lactobacillus acidophilus Enterococcus feacalis, Streptococcus pyogene and Staphylococcus aureus) with 0.1 mol/L, pH 7 phosphate buffer was prepared and homogenized in a digital high-speed homogenizer system (IKA-Ultra-Turrax, T18, USA; $1 \mathrm{~min}, 7847 \mathrm{~g}$ ). The resulting suspension $(1 \mathrm{ml})$ was distributed in disposable test tubes (containing $9 \mathrm{ml}$ of peptone water), and $0.1 \mathrm{~g}$ of the isolated total indigestible fraction from each bean was added. All incubations were performed in triplicate, and the corresponding tubes from samples and controls were analyzed for $\mathrm{pH}$ changes, turbidity at each fermentation time point. Each tube was mixed with $100 \mu \mathrm{L}$ of Sodium hydroxide at room temperature to stop the reaction. The tubes obtained at each time of fermentation were centrifuged (Hermle Z $323 \mathrm{~K}$; Wehingen, Germany) at 3500 for $15 \mathrm{~min}$ at $4^{\circ} \mathrm{C}$. Supernatants were divided into two parts: one was used for metabolite profile analysis (short chain fatty acids), and the other was used for Radical assays and identification of the glucose concentration. Samples were always kept at $-80^{\circ} \mathrm{C}$ until analysis.

\subsection{Determination of the Turbidity}

During fermentation, the absorbance level was assessed at $0,6,12$ and $24 \mathrm{~h}$ as a function of the fermenting medium turbidity. The absorbance was read at 540 $\mathrm{nm}$ via Camspec M106 Spectrophotometer (USA).

\subsection{Glucose Test (GT)}

Using commercially available Randox Kit $100 \mu \mathrm{l}$ of the supernatant and $100 \mu \mathrm{l}$ of the reagent was mixed and incubated for 25 minutes at $15^{\circ} \mathrm{C}$ to $25^{\circ} \mathrm{C}$. The absorbance of the standard $\left(\mathrm{A}_{\text {standard }}\right)$ was measured and the sample $\left(\mathrm{A}_{\text {sample }}\right)$ against the reagent blank within 60 minutes.

\section{Results and Discussion}

The seeds of beans (Otili, Feregede, Pakala and Oloyin) analyzed in this present study contains indigestible fraction called dietary fiber. The result of the fermentation process on introduction of several microorganisms involves change in turbidity and glucose level.

Fermentation occurring in the mono gastric gastrointestinal tract (GIT) is increasingly being recognized as having an important influence on health both of the GIT itself, and also of the host animal. From the point of view of GIT health, it is recognized that fermentation is important for gut motility, the improvement of energy yield, the production of vitamins, and the stimulation of gut immunity [29]. Figures 1-4 show the absorbance level during the fermentation period. Generally, the absorbance level increases as the fermentation period increases, implying that the population of each microorganism increases. Pakala fermented by Streptococcus pyogenes had the highest absorbance of 1.997 after 24 hours of 


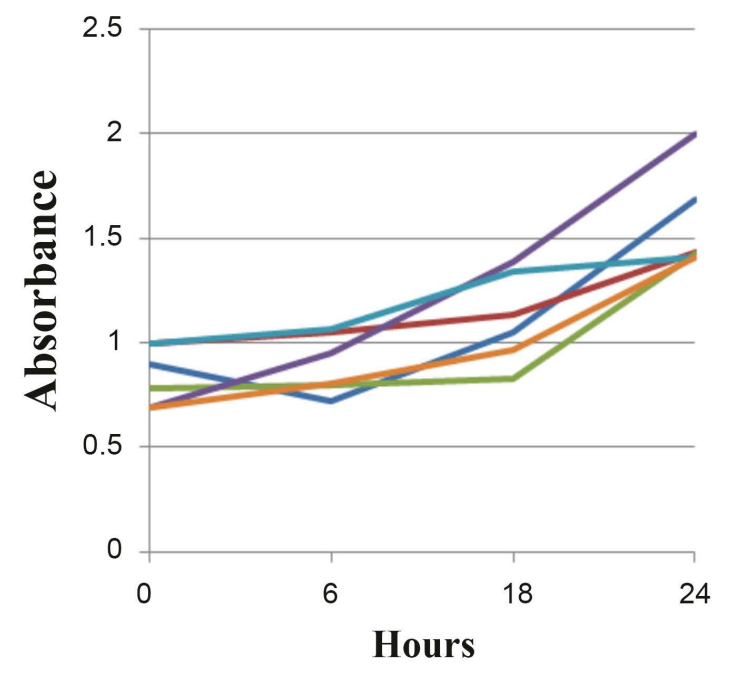

E. coli

Bacillus subtilis

Staphylococcus aureus

Streptococuus pyogenes

Enterococcus feacalis Lactobacillus
acidophilus

Figure 1. Absorbance of fermented Pakala.

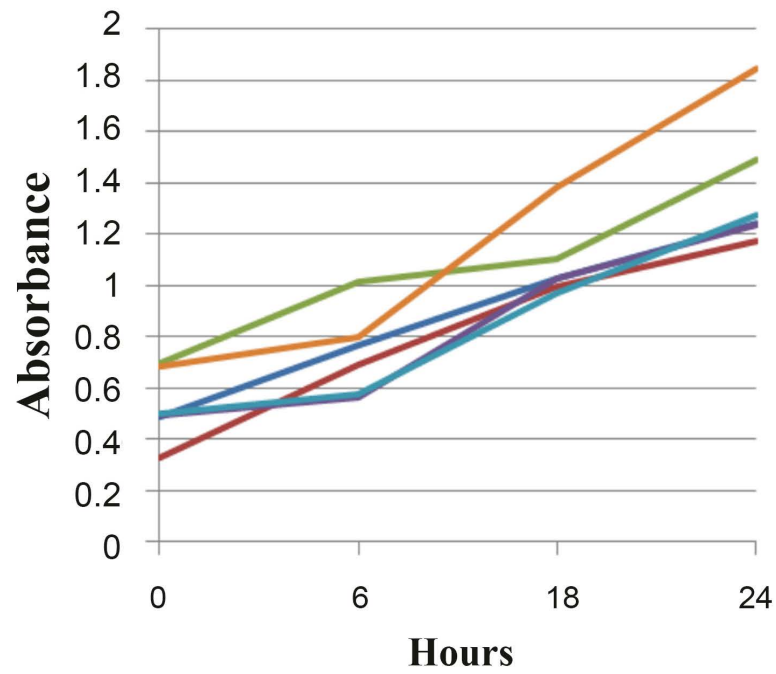

E. coli

Bacillus subtilis

Staphylococcus aureus

- Streptococuus pyogenes

Enterococcus feacalis

Figure 2. Absorbance of fermented Oloyin.
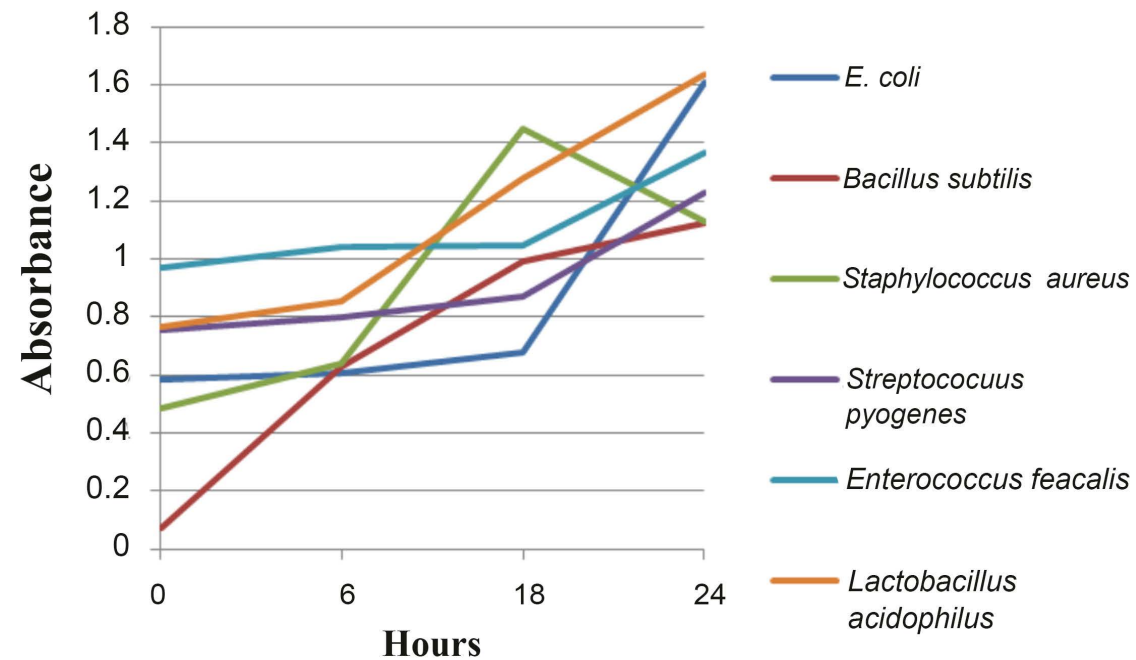

Figure 3. Absorbance of fermented Feregede. 


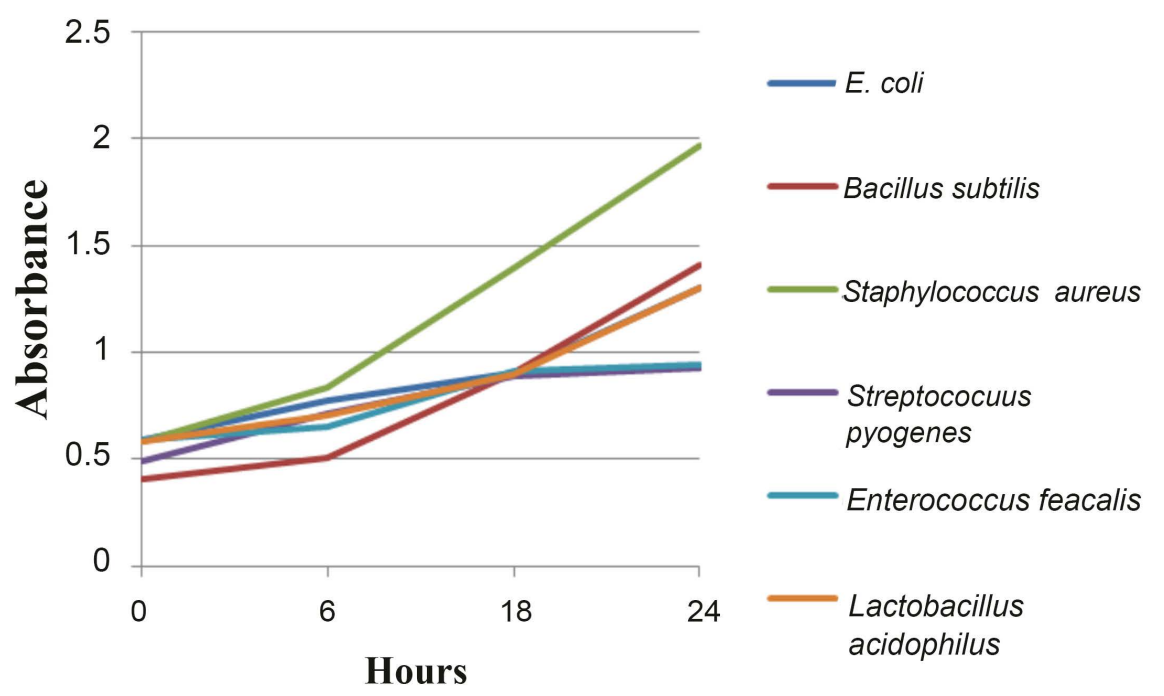

Figure 4. Absorbance of fermented Otili.

fermentation having a relative difference to that of Otili fermented by Staphylococcus aureus (1.969). At $0 \mathrm{hr}$, Pakala has the highest absorbance, Feregede as the next followed by Oloyin and Otili. After 24 hours of fermentation, Otili fermented by various microorganisms had its absorbance increased by $50 \%$. Pakala fermented by Streptococcus pyogenes had the highest absorbance of 1.997 after 24 hours of fermentation with a relative difference to that of Otili fermented by Staphylococcus aureus (1.969). In this study, the absorbance level increases as the fermentation period increases, implying that either the population of each microorganism increases or their respective metabolic products [16] [30].

From the absorbance level during the fermentation period, the turbidity level was observed as the microbial fermenters were increased per interval hours of 0 hr, $6 \mathrm{hrs}, 12 \mathrm{hr}, 18 \mathrm{hs}$ and $24 \mathrm{hrs}$. At $0 \mathrm{hr}$, microbial fermenters in pakala had the highest increasing level of $0.689-0.897$ while otili falling arise to $0.408-0.590$ in an increased level. At $6 \mathrm{hrs}, 0.718-1.061$ was obtained in microbes fermenters in pakala while microbes fermenters in otili had the least level of $0.507-0.838$. At $18 \mathrm{hrs}$, all the microbial fermenters had a minimum increasing level of absorbance. At 24 hrs, all the microbial fermenters had a minimum increasing level of absorbance except from otili which had its absorbance increased by $50 \%$.

Glucose test was used to examine glucose homeostasis during fermentation period (Figures 5-8). The glucose concentration for Oloyin fermented by Bacillus subtilis increased from $1.327 \mathrm{mmol} / \mathrm{L}(0 \mathrm{hr})$ to $4.795 \mathrm{mmol} / \mathrm{L}$ after $24 \mathrm{hr}$. Lactobacillus acidophilus fermenting Pakala had the highest concentration of glucose $(6.616 \mathrm{mmol} / \mathrm{L})$ followed by Otili fermented by Enterococcus feacalis $(5.861 \mathrm{mmol} / \mathrm{L})$. No difference was found in both Feregede fermented by Lactobacillus acidophilus and Otili fermented by Escherichia coli. From the result of the glucose of fermentation extract, Pakala fermented by Lactobacillus acidophilus had the highest concentration of glucose $(6.616 \mathrm{mmol} / \mathrm{L})$ followed by Otili fermented by Enterococcus feacalis $(5.861 \mathrm{mmol} / \mathrm{L})$. The glucose concentration 


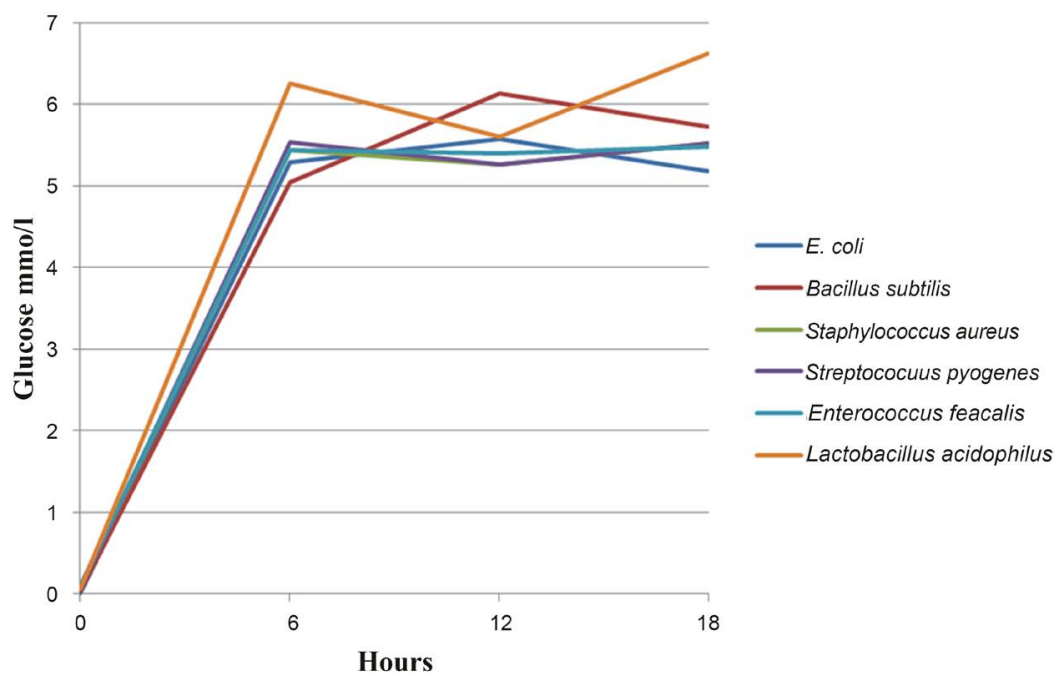

Figure 5. Glucose formation during fermentation of dietary fibre from Pakala.

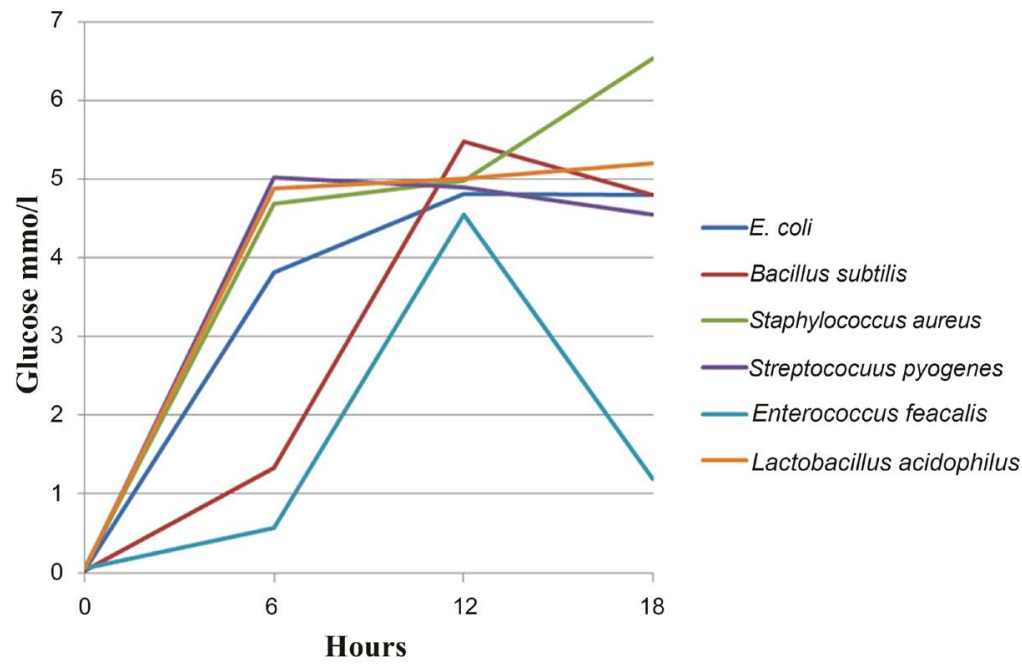

Figure 6. Glucose formation during fermentation of dietary fibre from Oloyin.

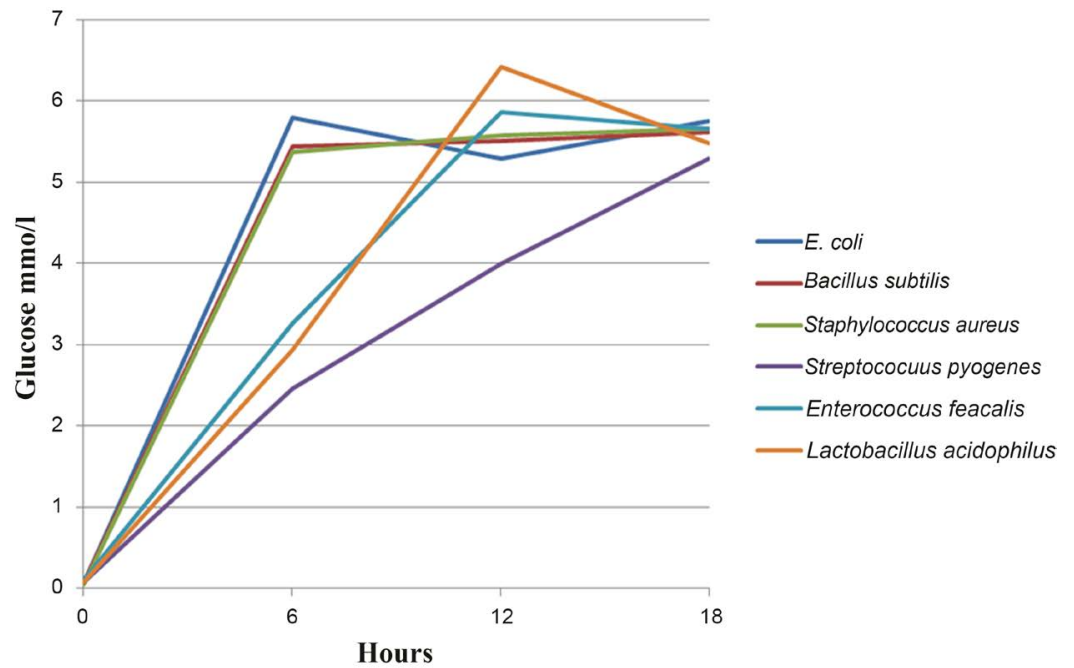

Figure 7. Glucose formation during fermentation of dietary fibre from feregede. 


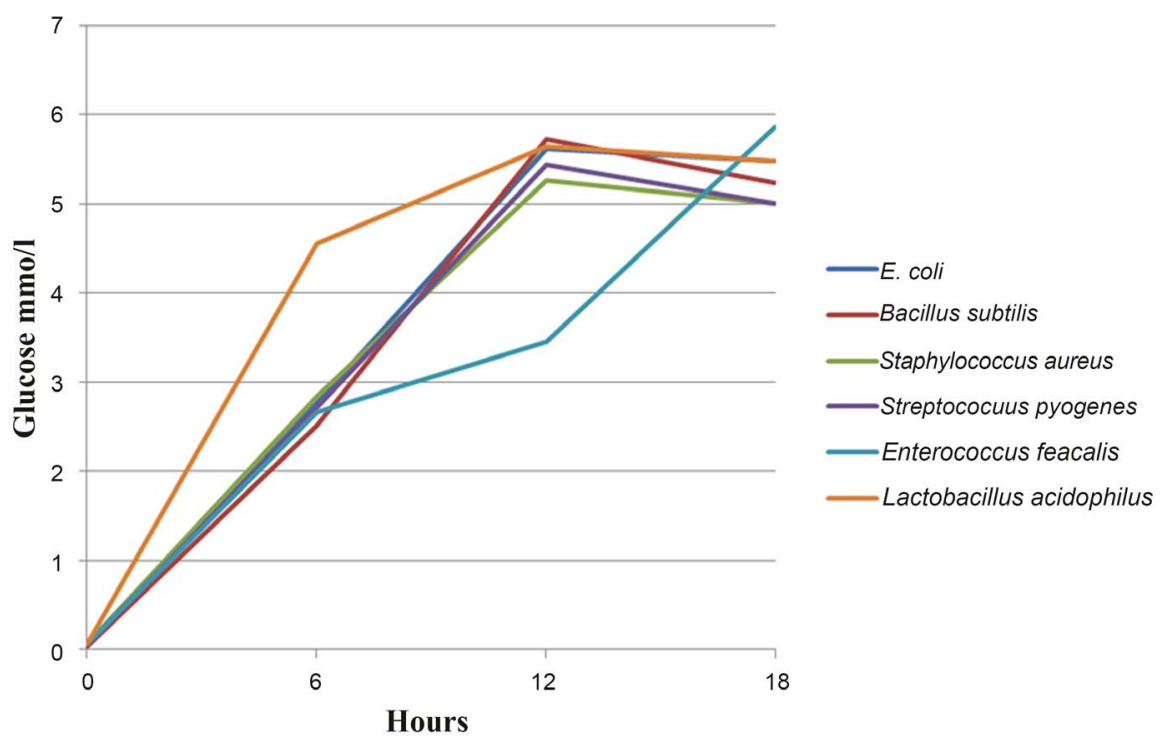

Figure 8. Glucose formation during fermentation of dietary fibre from feregede.

decrease with some exception such as Pakala fermented by Lactobacillus acidophilus which had the value of $6.260 \mathrm{mmol} / \mathrm{L}$ at $6 \mathrm{hr}$ and increased to 6.616 mmol/L after 18 hour. Probably the microbes Lactobacillus acidophilus and Enterococcus feacalis (Otili) having high glucose concentration may be as a result of high metabolic activity thus converting the oligosaccharide into simple sugar such as glucose for their growth. The ability of this organism to produce more glucose is explained by its higher affinity for the substrate [31] [32] [33].

\section{Conclusion}

This contribution shows the changes of microbiota metabolites, such as glucose as influenced by change in turbidity and $\mathrm{pH}$ during in vitro colonic fermentation of indigestible fraction isolated from three underutilised wild Nigerian beans. The magnitude of metabolite production, particularly glucose, during in vitro fermentation, was dependent on fermentation time and types of substrate. It should be noted that, through the study of foods frequently consumed by a population, it will improve our understanding of the effects of diet on colon health promotion.

\section{Acknowledgements}

The present project was partly funded by Tet Fund Individual Based Research grant 2017-2018 sessions. To embark on this study, the invaluable encouragement of Prof (Mrs) Rocio Campos-Vega of Autonomous University Queretaro, Mexico is highly acknowledged.

\section{Conflicts of Interest}

The authors declare no conflicts of interest regarding the publication of this paper. 


\section{References}

[1] Hermsdorff, H.H.M., Zulet, M.A., Abete, I. and Martínez, J.A. (2011) A Legume-Based Hypocaloric Diet Reduces Proinflammatory Status and Improves Metabolic Features in Overweight/Obese Subjects. European Journal of Nutrition, 50, 61-69. https://doi.org/10.1007/s00394-010-0115-x

[2] Marques, F.Z., Nelson, E., Chu, P.-Y., Horlock, D., Fiedler, A., Ziemann, M. and El-Osta, A. (2017) High-Fiber Diet and Acetate Supplementation Change the Gut Microbiota and Prevent the Development of Hypertension and Heart Failure in Hypertensive Mice Clinical Perspective. Circulation, 135, 964-977.

https://doi.org/10.1161/CIRCULATIONAHA.116.024545

[3] Wikoff, W.R., Anfora, A.T., Liu, J., Schultz, P.G., Lesley, S.A., Peters, E.C., et al. (2009) Metabolomics Analysis Reveals Large Effects of Gut Microflora on Mammalian Blood Metabolites. Proceedings of the National Academy of Sciences of the United States of America, 106, 3698-3703.

[4] Hood-Niefer, S.D., Warkentin, T.D., Chibbar, R.N., Vandenberg, A. and Tyler, R.T. (2012) Effect of Genotype and Environment on the Concentrations of Starch and Protein in, and the Physicochemical Properties of Starch from, Field Pea and Fababean. Journal of the Science of Food and Agriculture, 92, 141-150.

https://doi.org/10.1002/jsfa.4552

[5] Louis, P., El Aidy, S., van den Abbeele, P., van de Wiele, T. and Kleerebezem, M. (2013) Intestinal Colonization: How Key Microbial Players Become Established in This Dynamic Process: Microbial Metabolic Activities and the Interplay between the Host and Microbes. BioEssays, 35, 913-923.

[6] Sharon, G., Garg, N., Debelius, J., Knight, R., Dorrestein, P.C. and Mazmanian, S.K. (2014) Specialized Metabolites from the Microbiome in Health and Disease. Cell Metabolism, 20, 719-730. https://doi.org/10.1016/j.cmet.2014.10.016

[7] Richards, L.B., Li, M., vanEsch, B.C.A.M., Garssen, J. and Folkerts, G. (2016) The Effects of Short Chain Fatty Acids on the Cardiovascular System. Pharma Nutrition, 4, 68-111. https://doi.org/10.1016/j.phanu.2016.02.001

[8] Gibson, G.R., Macfarlane, G.T., Beatty, E. and Cummings, J.H. (1992) Estimation of Short-Chain Fatty Acid Production from Protein by Human Intestinal Bacteria Based on Branched-Chain Fatty Acid Measurements. FEMS Microbiology Ecology, 101, 81-88.

[9] Shanahan, F. (2002) The Host-Microbe Interact within the Gut. Best Practice \& Research: Clinical Gastroenterology, 16, 915-931. https://doi.org/10.1053/bega.2002.0342

[10] Santacruz, A., Collado, M.C., Garcia-Valdes, L., Segua, M.T., Martin-Lagos, J.A., Anjos, T., Marti-Romero, M., Lopez, R.M., Florido, J., Campoy, C. and Sanz, Y. (2010) Gut Microbiota Composition Is Associated with Body Weight, Weight Gain and Biochemical Parameters in Pregnant Women. British Journal of Nutrition, 104, 83-92. https://doi.org/10.1017/S0007114510000176

[11] Roediger, W.E. (1980) Role of Anaerobic Bacteria in the Metabolic Welfare of the Colonic Mucosa in Man. Gut, 21, 793-798. https://doi.org/10.1136/gut.21.9.793

[12] Russell, W.R., Hoyles, L., Flint, H.J. and Dumas, M.E. (2013) Colonic Bacterial Metabolites and Human Health. Current Opinion in Microbiology, 16, 246-254. https://doi.org/10.1016/j.mib.2013.07.002

[13] Luis, V., Sean, H. and Samantha, C. (2015) Metabolic Interactions in the Gastrointestinal Tract (GIT): Host, Commensal, Probiotics, and Bacteriophage Influences. 
Microorganisms, 3, 913-932.

[14] Hamer, H.M., Jonkers, D., Venema, K., Vanhoutvin, S., Troost, F.J. and Brummer, R.J. (2008) Review Article: The Role of Butyrate on Colonic Function. Alimentary Pharmacology \& Therapeutics, 27, 104-119. https://doi.org/10.1111/j.1365-2036.2007.03562.x

[15] Geier, M.S., Butler, R.N. and Howarth, G.S. (2007) Inflammatory Bowel Disease: Current Insights into Pathogenesis and New Therapeutic Options; Probiotics, Prebiotics and Synbiotics. International Journal of Food Microbiology, 115, 1-11. https://doi.org/10.1016/j.ijfoodmicro.2006.10.006

[16] Flint, H.J., Duncan, S.H., Scott, K.P. and Louis, P. (2007) Interactions and Competition within the Microbial Community of the Human Colon: Links between Diet and Health. Environmental Microbiology, 9, 1101-1111. https://doi.org/10.1111/j.1462-2920.2007.01281.x

[17] Danese, S. and Fiocchi, C. (2006) Etiopathogenesis of Inflammatory Bowel Diseases. World Journal of Gastroenterology, 12, 4807-4812. https://doi.org/10.3748/wjg.v12.i30.4807

[18] Breuer, R.I., Soergel, K.H., Lashner, B.A., Christ, M.L., Hanauer, S.B., Vanagunas, A., Harig, J.M., Keshavarzian, A. and Robinson, M. (1997) Short-Chain Fatty Acid Rectal Irrigation for Left-Sided Ulcerative Colitis: A Randomized, Placebo-Controlled Trial. Gut, 40, 485-491. https://doi.org/10.1136/gut.40.4.485

[19] Bajka, B.H., Clarke, J.M., Cobiac, L. and Topping, D.L. (2008) Butyrylated Starch Protects Colonocyte DNA against Dietary Protein-Induced Damage in Rats. Carcinogenesis, 29, 2169-2174. https://doi.org/10.1093/carcin/bgn173

[20] Aparicio-Fernandez, X., Yousef, G.G., Loarca-Pina, G., De-Mejia, E. and Lila, M.A. (2005) Characterization of Polyphenolic in the Seed Coat of Black Jamapa Bean (Phaseolus vulgaris). Journal of Agricultural and Food Chemistry, 53, 4615-4622. https://doi.org/10.1021/jf047802o

[21] Benoit, S.C., Kemp, C.J., Elias, C.F., Abplanalp, W., Herman, J.P., Migrenne, S., Lefevre, A.L., Cruciani-Guglielmacci, C., Magnan, C., Yu, F., Niswender, K., Irani, B.G., Holland, W.L. and Clegg, D.J. (2009) Palmitic Acid Mediates Hypothalamic Insulin Resistance by Altering PKC- $\theta$ Subcellular Localization in Rodents. Journal of Clinical Investigation, 119, 2577-2587. https://doi.org/10.1172/JCI36714

[22] Mentor-Marcel, R.A., Bobe, G., Barrett, K.G., Young, M.R., Albert, P.S., Bennink, M.R., et al. (2009) Inflammation-Associated Serum and Colon Markers as Indicators of Dietary Attenuation of Colon Carcinogenesis in ob/ob Mice. Cancer Prevention Research, 2, 60-69. https://doi.org/10.1158/1940-6207.CAPR-08-0086

[23] Riviere, A., Marija, S. and Luc-De, V. (2016) Bifidobacteria and Butyrate Producing Colon Bacteria: Importance and Strategies for Their Stimulation in the Human Gut. Frontiers in Microbiology, 7, 979.

[24] Baron, E., Peterson, L. and Finegold, S. (1994) Non-Fermentative Gram-Negative Bacilli and Coccobacilli. In: Bailey \& Scott's Diagnostic Microbiology, 9th Edition, Mosby-Year Book, St. Louis, 386-405.

[25] Benachinmardi, K.K., Padmavathy, M., Malini, J. and Naveneeth, B. (2014) Prevalence of Non Fermenting Gram-Negative Bacilli and Their in Vitro Susceptibility Pattern at a Tertiary Care Teaching Hospital. Journal of the Scientific Society, 41, 162-166. https://doi.org/10.4103/0974-5009.141204

[26] Blondel-Hill, E., Henry, E.A. and Speert, D.P. (2007) Pseudomonas. In: Manual of Clinical Microbiology, 9th Edition, American Society for Microbiology, Washington DC, 734-748. 
[27] Chang, S., Cui, X., Guo, M., Tian, Y., Xu, W., Huang, K. and Zhang, Y. (2017) Insoluble Dietary Fiber from Pear Pomace Can Prevent High-Fat Diet Induced Obesity in Rats Mainly by Improving the Structure of Gut Microbiota. Journal of Microbiology and Biotechnology, 27, 856-867. https://doi.org/10.4014/jmb.1610.10058

[28] Campos-Vega, R., Reynoso-Camacho, R., Pedraza-Aboytes, G., Acosta-Gallegos, J.A., Guzman Maldonado, S.H., Paredes-Lopez, O., Oomah, B.D. and Loarca-Piña, G. (2009) Chemical Composition and in Vitro Polysaccharide Fermentation of Different Beans (Phaseolus vulgaris L.). Journal of Food Science, 74, T59. https://doi.org/10.1111/j.1750-3841.2009.01292.x

[29] Zamora-Gasga, V.M., Álvarez-Vidal, C., Montalvo-González, E., Loarca-Piña, G., Vázquez-Landaverde, P.A., Bello-Pérez, L.A., Tovar, J. and Sáyago-Ayerdi, S.G. (2018) Gut Metabolites Associated with $\mathrm{pH}$ and Antioxidant Capacity during in $\mathrm{Vi}$ tro Colonic Fermentation of Mexican Corn Products. Cereal Chemistry, 95 399-410. https://doi.org/10.1002/cche.10039

[30] Falony, G., Vlachou, A., Verbrugghe, K. and De Vuyst, L. (2006) Cross-Feeding between Bidobacterium longum BB536 and Acetate-Converting, Butyrate Producing Colon Bacteria during Growth on Oligofructose. Applied and Environmental Microbiology, 72, 7835-7841. https://doi.org/10.1128/AEM.01296-06

[31] Mathers, J.C. and Annison, E.F. (1993) Stoichiometry of Polysaccharide Fermentation in the Large Intestine. In: Samman, S. and Annison, G., Eds., Dietary Fibre and Beyond-Australian Perspectives, Nutrition Society of Australia Occasional Publications, Vol. 1, 123-135.

[32] Mazotto, A.M., Rodrigues-Coelho, R.R., Lage-Cedrola, S.M., Lima, M.F., Couri, S., Paraguai de Souza, E. and Vermelho, A.B. (2011) Keratinase Production by Three Bacillus spp. Using Feather Meal and Whole Feathers as Substrate in a Submerged Fermentation. Enzyme Research, 2011, Article ID: 523780. https://doi.org/10.4061/2011/523780

[33] Hosoi, T., Ametani, A., Kiuchi, K. and Kaminogawa, S. (2000) Improved Growth and Viability of Lactobacilli in the Presence of Bacillus subtilis (Natto), Catalase, or Subtilisin. Canadian Journal of Microbiology, 46, 892-897.

https://doi.org/10.1139/w00-070 